\title{
Bir Konut Projesi Örneğinde İnşa Edilebilirlik Değerlendirme Yöntemlerinin Araştırılması
}

\author{
Illkay $\operatorname{KOMAN}^{1 * \odot, ~ S u n a ~ K A Y A}{ }^{2} \odot$ \\ ${ }^{1}$ Mimar Sinan Güzel Sanatlar Üniversitesi, Mimarlık Fakültesi, Mimarlık Bölümü, Yapı Bilgisi Anabilim \\ Dalı, 34427, istanbul, Türkiye. \\ ${ }^{2}$ Mimar Sinan Güzel Sanatlar Üniversitesi, FBE, Mimarlık Anabilim Dalı, 34427, İstanbul, Türkiye. \\ *e-mail: ilkay.koman@msgsu.edu.tr
}

Öz

Proje hedeflerine ulaşmak için planlama, mühendislik, şantiye alanında ve satın alma süreçlerinde inşaat bilgisi ve deneyiminin birlikte optimum kullanımına yönelik sistemleri, yöntemleri geliştirmeyi amaçlayan çalışmaların başında inşa edilebilirlik değerlendirme yöntemleri gelir. Bu çalışma inşa edilebilirlik değerlendirme yöntemlerinin ve iki farklı inşa edilebilirlik değerlendirme yönteminin detaylı olarak incelenmesini kapsamaktadır. Örnek bir konut projesinin inşa edilebilirlik sistemlerinden aldığı puanlar yorumlanmış, elde edilen bulgular karşılaştırılmıştır. Mevcut sistemler büyük ölçekli projelerin değerlendirilmesi için kullanılmak üzere geliştirilmiş, inşaatta verimliliğe odaklanan sistemlerdir. Çalışmada özellikle kentsel dönüşüm projelerinde gerçekleştirilmekte olan projelerin inşa edilebilirlik değerlendirmesinin yapılmasının önemi ortaya koyulmuştur. Çalışma, ülkemiz için geliştirilecek inşa edilebilirlik değerlendirme yöntemlerine zemin hazırlaması açısından önemlidir.

Anahtar Kelimeler: Inşa edilebilirlik, inşa edilebilir tasarım, yapı değerlendirme yöntemleri.

\section{Research of Constructability Assessment Methods; Housing Case Study}

\begin{abstract}
Constructability assessment methods are at the head of the works aiming to develop systems and methods for the optimum use of construction knowledge and experience in planning, engineering, construction site and procurement processes in order to achieve the project objectives. This study includes a detailed examination of constructability assessment methods. The scores of a sample housing project from constructability systems were interpreted and the findings obtained were compared. Existing systems are developed to be used for the evaluation of large-scale projects, focusing on efficiency in construction. In the study, the importance of the constructability assessment of the projects in this scope, which are carried out especially in reconstruction projects to be carried out in urban areas, has been revealed. The study is important in terms of laying the ground work for constructability assessment methods to be developed for our country.
\end{abstract}

Keywords: Constructability, buildability, building assessment methods.

Atıf/Citation: Koman, İ. ve Kaya, S. (2020). Bir Konut Projesi Örneğinde İnşa Edilebilirlik Değerlendirme Yöntemlerinin Araştırılması. Mimarlık Bilimleri ve Uygulamaları Dergisi, 5(2), 135-150.

DOI: $10.30785 / \mathrm{mbud} .785500$ 


\section{Giriş}

Günümüzde yeni malzemeler ve teknolojiyle beraber gelişen yapım yöntemleri kullanılarak oldukça maliyetli ve karmaşık projeler tasarlanmakta, bununla birlikte tasarım aşamasında yapıların inşası ile ilgili kararlar çoğunlukla uygulama aşamasına bırakılmaktadır. Bunun sonucu olarak, inşaat aşamasında birçok sorunla karşılaşılabilmektedir. İnşaat projelerinin tasarımı ve inşası; işveren, yüklenici, alt yüklenici, mühendis, mimar ve iş̧̧i gibi farklı meslek gruplarında kişilerin bir araya gelerek, koordinasyon içinde çalışmalarını gerektiren karmaşık bir süreçtir. Projelerin başarıyla tamamlanabilmesi için çeşitli aşamalarda sürece dâhil olan insanların arasındaki iletişimin iyi kurulması ve iş birliğine dayalı bir ortam yaratılması gerekir (ilter, 2010). Ayrıca projelerin ilk kavramsal tasarım aşamasından teslimine kadar; süre, maliyet, insan kaynakları, iletişim, risk, tedarik ve kalite kontrolü için hazırlanan tüm prosedürleri kapsayacak şekilde yönetilmesi günümüzde zorunluluk haline gelmiştir. Bu bağlamda yürütülen bilimsel ve sektörel çalışmalar; proje yönetimi, yapım yönetimi ve inşa edilebilirlik değerlendirmesi başıklarında yoğunlaşmaktadır. İnşa edilebilirlik, 1960'lardan itibaren; projelerde kaliteyi artırmak için inşaat bilgisini ve deneyimini en uygun şekilde kullanan proje yönetim sistemlerini kapsayan bir araştırma alanı olarak gündeme gelmiştir. İnşa edilebilirliğin inşaat sektöründe yaşanan problemleri çözebileceği İngiltere, Amerika Birleşik Devletleri, Avusturalya, Hong Kong ve Singapur gibi çeşitli ülkelerde yapılan çok sayıdaki araştırmalarla ortaya konmuştur.

Ingiltere'de inşa edilebilirlik ile ilgili yapılan ilk çalışmalar, tasarımın rasyonelleştirilmesi ile üretkenliğe odaklanması dar kapsamlı olarak eleştirilmiş ancak, ülkede tasarım ve yapım entegrasyonunu teşvik etme konusundaki öncü çabadan dolayı itibar kazanmıştır (Wong vd., 2006). İngiltere hükümetinin 1962 tarihli Emmerson Raporu'nda, tasarım ve yapım süreçlerinin birbirinden ayrılması sonucu ortaya çıkan iletişim ve koordinasyon yetersizlikleri konusundaki endişeler dile getirilmiştir (Wong, Lam ve Shen, 2004). Emmerson Raporu'ndan sonra; İngiltere'de inşa edilebilirlik sorunlarını nedenleriyle belirlemek ve çözüm aramak için çok sayıda araştırma yapıımıştır. Ayrıca; 1964 tarihli Banwell Raporu'nda inşaat bilgisi yetersiz tasarımcılar tarafından tasarlanan verimsiz projeler ve müteahhitlerin tasarım sürecine dâhil olmamaları vurgulanmış, inşa edilebilirliğin oldukça yetersiz olduğu ortaya konulmuştur (Wong, 2007). Bu bulgular ışığında, Yapı Endüstrisi Araştırma ve Bilgi Birliği (CIRIA) 1979 yılında tasarımın değer ve süreç açısından genellikle yetersiz kaldığı sonucuna varmış ve "inşa edilebilirlik" kavramını geliştirmiştir (Wong vd., 2004). 1983 yılında da CIRIA tarafından geleneksel tedarik sistemine göre tasarımcıları hedefleyen bir kılavuz hazırlanmıştır (Wong, 2007). 1983 yılında Gray ve 1984 yılında Griffith, inşa edilebilirliğin geliştirilmesini kolaylaştırmak için sözleşme kullanarak, inşaat uzmanlarının tasarımın erken aşamasında sürece dâhil olmalarını önermiştir. Tasarım odaklı faktörlerin yanı sıra, verimli yönetimin iyi inşa edilebilirlik ve üretkenlik elde etmek için hayati olduğu düşünülmüştür (Wong, 2007). Adams (1989) da tasarım ekibinin, inşa edilebilirliği tasarıma entegre etme sorumluluğu üstlenmesi gerektiğini dile getirmiş ve CIRIA'nın ilkelerine göre pratik ve açıklayıcı örneklerle 16 inşa edilebilirlik ilkesini geliştirmiştir. Aynı yıl, Ferguson, "bir binanın verimli, ekonomik ve yapı malzemelerinden, bileşenlerinden ve montajlarında kararlaştırılan kalite seviyelerinde bir bina inşa etme kabiliyeti" olarak inşa edilebilirliği tanımlamıştır. Bu tanım, proje amaçlarına ulaşmak için proje faaliyetlerinin ve inşaat sürecinin optimum yönetimi ve yapılandırılmasını vurgulamıştır. 1980'lerin sonunda, inşaat endüstrisinin ağırlıklı olarak parçalanmış doğası ve rasyonelleştirmeyle geliştirilen bina tiplerine yönelik eleştiriler nedeniyle İngiltere'de inşa edilebilirliğe olan ilgi azalmıştır. 1998 yılında inşa edilebilirlik performansı konusundaki endişeyi tekrar ortaya çıkaran Egan Raporu'nda, standartlaştırılmış bileşenlerin ve işlemlerin yanı sıra tasarım kalitesini ve verimliliğini artırmak için bilişim teknolojisinin kullanılması önerilmiştir (Wong vd., 2004).

Amerika Birleşik Devletleri'nde inşa edilebilirlik destekleyicilerinin benimsemiş olduğu yaklaşım, temel olarak maliyet, program, kalite ve diğer proje faydalarını elde etmek için kullanılan yönetim sistemine odaklanmaktadır. CII inşa edilebilirliğin tanımını; genel proje hedeflerine ulaşmak için planlama, tasarım ve şantiye uygulamalarında en fazla inşaat bilgisi ve tecrübesinin kullanılması olarak ortaya koymuştur (Wong vd., 2004). İyi bir inşa edilebilirlikten kazanılacak faydalar 1982 yılında, $A B D$ ekonomisini teşvik etmek için New York'da kurulmuş olan bir kurum olan Business 
Roundtable tarafından yayınlanan raporda "bunu başarmanın maliyetinin, yaklaşık 10 ila 20 katı" olarak belirtilmiştir. Bu açıklamadan sonra Yapı Endüstrisi Enstitüsü (CII) tüm proje aşamaları için inşaat girdilerini ve bir projenin farklı aşamalarında inşa edilebilirlik tasarruflarının incelenmesini teşvik etmiştir. İlerleyen yıllarda inşa edilebilirliğin geliştirilmesi için kavramsal tasarım, mühendislik, tedarik ve yapım alanlarında araştırmalar yapılmıştır. Ayrıca CII 1987 yılında, inşa edilebilirliğin uygulanması için gereklilikleri belirleyen kavramsal planlama aşaması için 6 , tasarım ve tedarik aşamaları için 7, saha (şantiye) operasyonları aşaması için 1 olmak üzere 14 tanımlanmış konsepti içeren inşa edilebilirlik programının uygulanması için kılavuz yayınlamıştır. Ancak şimdiye kadar puanlama sistemi kurulmadığı için bu kılavuzdaki 14 tanımlanmış yaklaşıma göre bir projenin inşa edilebilirliğini doğrudan ölçmek mümkün olmamıştır (Wong, 2007).

Avusturalya'da inşa edilebilirlik kapsamında "inşa edilebilir tasarım" ve "inşa edilebilirlik" kavramları birbirinin yerine kullanılmıştır (Lam, Wong ve Chan, 2006). Ireland 1985 yılında, yönetimsel faaliyetlerin yüksek katlı ticari bina projelerinin maliyet, zaman ve kalite performansındaki rolünü incelediği çalışmasında; Avustralya yapı endüstrisinin inşaat hızı açısından yavaş ve sorunlu olduğunu, inşaat süresi ve maliyetinin tasarım-yapım sürecindeki koordinasyonla ve iyi bir inşaat (yapım) planlaması yapılmasıyla azalacağını ifade etmiştir. 1992 yılında CII Avusturalya inşa edilebilirliği; Avustralya yapı endüstrisine önemli maliyet ve zaman tasarrufu sağlama potansiyeline sahip bir yaklaşım olarak tanımlamıştır. O zamanlar Avustralya'da inşa edilebilirlikle ilgili çok az araştırma yapılmış ve değer mühendisliği oldukça yaygın kullanıımıştır. Tasarımın büyük ölçüde geliştirildiği bu noktada uygulanma aşamasında en fazla tasarruftan mahrum kalınmıştır. CII Avusturalya; müşteri, mimar, yapı mühendisi, miktar araştırmacısı (maliyetler ve sözleşmeler hakkında tasarımcı ve yüklenici arasında bağlantı yapan önemli kişidir), proje yöneticisi, inşaat mühendisi ve araştırmacıların dikkatlice dengelenmiş üyeliği ile İnşa Edilebilirlik Görev Gücü'nü (Constructability Task Force) kurmuştur. Amaçları, mevcut bilgi ve uygulamaları değerlendirmek ve Avustralya endüstrisine uygun inşa edilebilirlik yaklaşımı geliştirmekti. Bundan dolayı öncelikli olarak inşa edilebilirlik uygulamalarının önündeki engellerin kaldırılması ve şirketlerin inşa edilebilirlik sayesindeki kazanımlarının farkında olmalarını sağlamak için vaka çalışmaları yapılmıştır. Bu çalışmalar sonucunda başarılı bir inşa edilebilirlik uygulamasının sağlanması için ele alınması gereken on iki uygulama stratejisi ve inşa edilebilirlik sistemi için destekleyici belgelerden oluşan İnşa Edilebilirlik Kılavuzu yayınlanmıştır. Ayrıca; Newcastle'daki Yapı Performans Araştırma Grubu da (The Building Performance Research Group) inşa edilebilirliğin stratejik yönetimi için bir sistem çerçevesi önermiş ve inşa edilebilirliğin bir binanın tamamlandıktan sonraki süreyi de içeren tüm yaşam döngüsünü kapsaması gerektiğini öne sürmüştür. Bilgi yönetimindeki eksiklikten etkilenen inşa edilebilirliği, bina satın alma süreçlerinin tamamında alınan kararların, projeyi ve diğer proje hedeflerini sağlamadaki faktörlere cevap olarak, nihai olanaklarla tamamlanan projenin kalitesi ve yapımını kolaylaştırdığı şeklinde tanımlamışlardır (Francis vd., 1999).

Singapur, inşa edilebilirliğin ölçülmesi ve geliştirilmesinde gerekli yönergeleri formüle edip kullanılmasını zorunlu kılan ilk ülkedir. İnşa edilebilirliği ölçmek için; bir Japon müteahhitlik şirketinde kullanılan inşa edilebilirlik değerlendirme sistemi model alınarak inşa Edilebilir Tasarım Değerlendirme Sistemi (BDAS) geliştirilmiştir. İlk zamanlarda BDAS teşvik edici olmasından dolayı kullanılmış sonra hükümet inşa edilebilir tasarımların yasalarla zorunlu hale getirilerek uygulanmasına karar vermiştir. 2001 yılından itibaren Yapı Denetimi Yasası gereğince, teslim edilen yapı planlarının onaylanabilmesi için önce en az inşa edilebilirlik puanını sağlaması gerekmektedir. Kalifiye kişiler yapı projesinin tamamlanmasından sorumlu olacak ve yasal yükümlülüğünü yerine getirmek için projenin inşa edilebilirlik puanını beyan edecektir (Wong vd., 2004). Bir tasarımın inşa edilebilirlik açısından değerlendirildiği temel tasarım ilkesi olan; standardizasyon, basitlik ve tek bütünleşik öğeleri içermesi BDAS'ın temel unsurlarıdır. Tasarımcıların kullanılacak en uygun bina sistemini belirledikten sonra tasarımlarını geliştirmede dikkate alması gereken unsurlardır. İnşa edilebilirlik puanları, farklı inşaat sistemlerinin kullanılmasıyla elde edilebilecek iş gücü tasarrufunun göreceli önem derecesine göre verilmektedir. Daha yüksek puan alan tasarımlar genellikle daha fazla inşa edilebilirdir ve müteahhit daha az şantiye çalışanına ihtiyaç duymaktadır (Lam vd., 2006). 
Hong Kong inşaat endüstrisinde, inşaat süreci ve inşa ürünlerinde birçok sorun tespit edilmiştir. Belirlenen sorunları iyileştirmek ve önlemler önermek üzere kurulan Yapı Endüstrisi Değerlendirme Komitesi (CIRC), tasarımların inşa edilebilirliğine erken ve daha fazla önem verilmesinin, maliyet ve iş gücü tasarrufu sağlayan inşaat teknolojilerinin benimsenmesinin malzeme israfını en aza indireceğini belirtmiştir (Lam, vd. 2006). Bu nedenle bir projede inşaat atıklarının azaltılmasını ve verimliliğin artırılmasını sağlayan prefabrik, standart ve modüler bileşenlerin kullanımı ile zayıf inşa edilebilirliğin iyileştirilebileceği önerilmiştir (Wong vd., 2004). Ayrıca; yetki verilmiş yönetim personelinin tasarımdan proje tamamlamaya kadar bir bütün "sistemler" yaklaşımını kullanmalarını önermiştir. Sonuç olarak, CIRC bir projenin başlangıcında daha ayrıntılı ve düşünceli planlanmasını teşvik etmiştir (Lam, vd. 2006).

\subsection{Problem alanı, kapsam ve amaç}

Yukarıda tarihsel gelişimi özetle açıklanan inşa edilebilirlik çalışmalarında, genel proje hedeflerine ulaşmak için planlama, mühendislik, şantiye alanında ve satın alma süreçlerinde inşaat bilgisi ve deneyiminin birlikte optimum kullanımına yönelik sistemleri, yöntemleri geliştirmeyi amaçlanmıştır. Geliştirilen değerlendirme yöntemlerinin, özellikle Singapur'da yerel otoriteler tarafından inşaat ruhsatı başvurularında proje onayı ve ön değerlendirme süreçlerinde kullanılan yasal bir zorunluk olarak yerini alması dikkate değerdir.

Inşa edilebilirlikte disiplinler arası entegrasyonun planlanması, geliştirilmesi ve kontrolü inşaat sektöründe en önemli konudur (Zolfagharian, Nourbakhsh, Mydin, Zin ve Irizarry, 2012). İnşaat öncesi planlama ve tasarım aşamasında, inşaat bilgisi ve deneyim entegrasyon eksikliği projenin yapımı aşamasında birçok inşa edilebilirlik sorunlarına yol açabilmektedir. Bu yüzden inşa edilebilirlik projelerin başarısını veya başarısızlığını ölçmede de önemli bir faktördür (Kamari ve Pimplikar, 2012). $\mathrm{Bu}$ bağlamda inşa edilebilirlik değerlendirme yöntemlerinin ve güncel yapım pratiklerine uygunluğunun araştırılması çalışmanın problem alanı olarak seçilmiştir. Bu makalede uygulamaya dönüşmüş olan değerlendirme sistemlerinin karşılaştırmalı olarak incelenmesi, bulguların güncel sektörel ihtiyaçlara göre yorumlanarak öneriler oluşturulması amaçlanmıştır.

\section{Yöntem}

$\mathrm{Bu}$ araştırmanın yürütülmesinde genel tarama modeli kullanılmıştır. Ayrıca; örnek projeden elde edilen veriler inşa edilebilirlik değerlendirme sistemleri kullanılarak nicel (kantitatif) araştırma yöntemiyle değerlendirilmiştir.

Çalışmanın literatür özeti; kavramsal çerçevenin oluşturulması için zemin teşkil eden inşa edilebilirlik kavramını inceleyen çalışmaların taranması ve inşa edilebilirlik değerlendirme yöntemlerinin incelenmesini kapsamaktadır. Bir sonraki aşamada aktif olarak uygulanmakta olan iki farklı inşa edilebilirlik değerlendirme yöntemi detaylı olarak incelenmiş, değerlendirme kriterleri ve puanlama sistemleri açıklanmıştır. Bu sistemlerin aynı örnek proje bağlamında karşılaştırılması çalışmanın bir sonraki aşamasını oluşturur. Bu kapsamda örnek proje üzerinden elde edilen bulguların karşılaştırıması, yorumlanması ve önerilerin oluşturulması ile çalışma sonuçlandırılmıştır. Çalışma, ülkemiz için geliştirilecek değerlendirme yöntemlerine zemin hazırlaması açısından önemlidir.

\section{1. İnşa edilebilirlik değerlendirme yöntemleri}

Inşa edilebilirlik çalışmaları literatürde; birbiriyle ilişkili "yapı tasarımı odaklı inşa edilebilirlik" (buildability) ve "yapı üretimi odaklı inşa edilebilirlik" (constructability) olmak üzere iki ayrı başlıkta yer alır. "Yapı tasarımı odaklı inşa edilebilirlik" üretilen projelerin tasarım aşamasından itibaren kaliteli, inşaat kolaylığı sağlayan, inşaatta ekonomi ve verimliliği hedefleyen bir yaklaşımı içerir. "Yapı üretimi odaklı inşa edilebilirlik" ise; proje hedeflerine ulaşmak için bina yapım sürecindeki çeşitli aşamaları kapsayan, farklı proje aşamalarında inşaat bilgisi ve deneyiminin optimum kullanımını da içeren daha geniş kapsamı ifade eder. Çizelge 1'de özetlenen her iki başlıktaki araştırmaların ortak özelliği bir bina tasarımında inşaat kaynaklarının verimli bir şekilde kullanılmasını ve müşterinin gereksinimleri karşılanırken, şantiyede inşaat kolaylı̆̆ı ve güvenliğinin artırılması hedeflemesidir (Çizelge 1). 
İnşa edilebilirlik üzerine yapılan kavramsal çalışmaların uygulamaya dönüşmesi inşa edilebilirlik değerlendirme yöntemleri üzerine yapılan araştırmalar ve geliştirilen sistemlerle mümkün olmuştur. Inşa edilebilirlik değerlendirmesi; uygun planlama ve modern yapım tekniklerinin kullanımı ile yapım sürecinde daha az atık üretilmesini sağlamak, maliyeti düşürmek ve program kesinliğini arttırmak için kullanılan, binaya ait bilgilerin kullanılarak fizibilitesi ile ilgili tüm faktörlerin kapsamlı bir analizi ve değerlendirmesidir. İnşa edilebilirlik değerlendirmesine yönelik olarak literatürde yedi adet değerlendirme yöntemi bulunmaktadır. Bunlar: Regresyon Analizi Yöntemi, Uzman Sistem Yöntemi, Yapay Sinir Ağı Yöntemi (ANN), Bulanık Mantık Yöntemi, BAM (Buildability Assessment Model) İnşa Edilebilirlik Değerlendirme Modeli, BDAS (Buildable Design Appraisal System) İnşa Edilebilir Tasarım Değerlendirme Sistemi ve CAS (Constructability Appraisal System) İnşa Edilebilirlik Değerlendirme Sistemi'dir.

Çizelge 1. Inşa edilebilirlik kavramları ve özellikleri

\begin{tabular}{l} 
Kavram \\
\hline Yapı tasarımı odaklı inşa edilebilirlik \\
(buildability) \\
- $\quad$ Tasarım kabiliyeti \\
- $\quad$ Kalite \\
- $\quad$ Yapım Kolaylığı \\
- $\quad$ Verimli ve ekonomik yapım
\end{tabular}

\section{Özellikler}

Bütün bir yapı üretim süreci boyunca, proje amaçlarını, yapım kolaylığıı ve kalitesini etkileyen faktörlerin kapasitesi (McGeorge, Chen ve Ostwald, 1992)

Bir yapının bileşen malzemesinden, ürünlere ve montaja kadar verimli, kaliteli, ekonomik inşa edilebilme kabiliyeti (Ferguson, 1989).

Bir tasarımın, kalite, estetik, zaman ve maliyet gibi faktörlere dayanarak bilinçli bir şekilde daha inşa edilebilir hale getirilmesi (Griffith, 1987).

Bir yapı tasarımının, yapımı tamamlanmış bir yapının gereksinimlerine göre yapım kolaylığı sağlayabilme kapasitesi (CIRIA, 1983).

Yapım kolaylığı ve daha az nitelikli usta intiyacı nedeniyle, standardizasyon, basitlik ve tek bütünleşik elemanların inşaatta kullanımının sağlanması (BCA, 2005).

Yapım kaynaklarını verimli ve ekonomik kullanarak, bir projenin bütün bakış açılarından ele alınması; iş gücü, malzeme, ürünler ve montajın yönetimi ile işin sürekliliğinin sağlanması (Low ve Abeyegoonasekera, 2001).

Yapı üretimi odaklı inşa edilebilirlik Kavramsal planlama/ tasarım/ mühendislik/ üretim ve saha operasyonları gibi bütün proje (constructability)

- Yapım bilgisi ve deneyimi aşamalarında kaynaklar, teknoloji ve deneyimin en iyi şekilde kullanılması ve bütünleşmesi (CII, 1986; Anderson vd., 1995; Arditi vd.,2002).

Bütün bir yapı üretim süreci boyunca, proje amaçlarını, yapım kolaylığını ve kalitesini etkileyen faktörlerin kapasitesi (McGeorge vd., 1992)

Yapımın kolaylığı, kalitenin, güvenliğin ve verimliliğin artması, inşa süresinin kısalması, iş tekrarının azalması için yapılması gereken her şey (Kerridge, 1993).

Bir yapım projesinin planlama, tasarım ve saha operasyonlarının yapım odaklı düşünülmesi (Pepper, 1994).

Proje gelişim sürecinde yapım bilgisinin katılımı ile proje amaçları ve yapı performansı arasındaki dengenin en uygun düzeyde sağlanması (CII, 1996).

Regresyon Analizi Yöntemi Touran (1988), yapı elemanları düzensizliklerinin kalıp verimliliği üzerindeki etkilerini ölçmek için kullanmıştır. Bu yöntemde aşağıdaki denklem kullanılarak yapı elemanlarındaki düzensizliklerin, kiriş alanı, verimlilik oranı, toplam işçi sayısı ve çalışma süreleri arasındaki ilişkilere etkisi değerlendirilmektedir. Touran hesaplamada; $\sum_{i=1}^{n} A_{i j} X_{i}=Y_{j}$ denklemini kullanmıştır. Burada; $A=$ kirişin alanı, $X=$ verimlilik oranı, $Y=$ toplam işçi-saat, $n=$ bilinen verimlilik oranının toplam sayısı, $J=$ kat sayısıdır. Regresyon yöntemi ile inşaatta her kat için verimlilik oranlarının sabit kalmaması ve yapı elemanları açısından değişik varyasyonlar değerlendirilememektedir. Bu olumsuz özelliği nedeniyle inşa edilebilirlik değerlendirmesinde kullanılmasının özellikle tasarım esnekliği anlamında kısıtılıklar getirdiği belirlenmiştir (Quing, 2004).

Uzman sistem yöntemi, bilinen gerçeklerden bir sonuca varmak için kurallarla ifade edilmiş akıl yürütme çizgilerini takip eden bir bilgi sistemidir. Bu yöntem, inşaat endüstrisindeki problemlerin gözden geçirilmesi ve inşa edilebilirlik değerlendirmelerinde yaygın olarak kullanılmaktadır. Örneğin; 1991 yılında Fischer, tasarımcıların daha inşa edilebilir bir betonarme yapı sistemine ulaşmaları için bir prototip uzman sistemi geliştirmiştir. 1992 yılında ise Alkass, Jergeas ve Tyler, bir tasarım detayının inşa edilebilirliğini değerlendirmek amacıyla "Ayrıntılı Tasarım Sistemi için İnşa Edilebilirlik Değerlendirmesi" adlı bilgisayar tabanlı bir prototip uzman sistemi geliştirmişlerdir. Klasik uzman sistem tekniklerinin inşa edilebilirlik değerlendirmeleri açısından bazı dezavantajları bulunmaktadır. Uzman sistem teknikleri üretim kurallarına uymayan "sağduyu" bilinçaltı kullanımını içeren sorunları çözememektedir. Uzmanlık alanları genellikle dar ve sınırlarında kırılgandır. Oysa en pratik yapı 
sorunları, sezgisel düşünceye ve profesyonel uzmanlığa bağlı olarak çözülebilmektedir. Bu nedenle, klasik uzman sistem tekniklerinin, inşa edilebilirlik alanındaki problemleri çözmede sınırlılıkları mevcuttur. Geleneksel uzman sistem tekniğinin dezavantajlarının üstesinden gelmek için, karar destek sistemi QFD (kalite fonksiyon dağılımı), bulanık küme teorileri ve bulanık sistemler olmak üzere üç teknik birleştirilerek uzman destek sistemleri geliştirilmiştir. QFD, farklı disiplinleri inşa edilebilir tasarımların karar verme süreçlerine entegre ederek uzmanlığı genişletmek için bir çerçeve sunmaktadır. Bulanık küme teorileri, inşa edilebilir tasarımlarda yer alan "sağduyuyu" yakalamak için, bulanık sistemlerde, inşa edilebilir tasarımlardaki bilgi ve tecrübeyi kullanmak için daha esnek, ekonomik ve güvenilir bir yol sağlamaktadır (Quing, 2004).

Yapay sinir ağları (ANN) öğrenme, ilişkilendirme ve eğitim modellerinden veya verilerden genellemede biyolojik sinir sistemlerini taklit etmek için geliştirilmiştir. 1999 yılında Yu ve Skibniewski bulanık yapay sinir ağı yöntemini kullanarak, inşaat teknolojilerinin gelişimi ve inşa edilebilirlik analizi için İnşaat Teknolojisi Seçici (Construction Technology Selector) adlı bir prototip bilgisayar sistemi geliştirmişlerdir. Sistemin iki temel işlevi vardır. Birincisi, sistem, sinir ağlarının ve genetik algoritmaların öğrenme yetenekleri ile bulanık mantık kombinasyonu yoluyla inşa edilebilirlik bilgisini otomatik olarak edinebilir. íkincisi, sistem nöro-bulanık bilgiye dayalı çok kriterli karar destek sistemi ile inşaat teknolojisi alternatiflerini değerlendirebilir (Barai ve Nair, 2004). ANN'ler, özellikle nörobulanık yöntem, inşa edilebilirlik incelemeleri ve değerlendirmelerinde bilgi edinme problemlerini çözmek için umut verici yöntemlerdir. Bununla birlikte, yöntemlerin bazı sınırlamaları vardır ve bunlar: ANN'ler kara kutu yöntemleridir; ANN'ler, tahmin edilecek tipik büyük parametreler nedeniyle aşırı takılma problemlerine eğilimlidir; ANN'ler de sıkıcı deneyler ve deneme-yanılma prosedürleri sıklıkla kullanılır; ANN'ler genellikle eğitim için daha fazla veri-zaman gerektirir ve ANN'ler veri güdümlü olup modelden bağımsızdırlar, bu nedenle de gözlemlenen belirli bir örneğe çok bağımlı olabilirler. İņ̧a edilebilirlik değerlendirmesi ve gözden geçirmeleri için, karar vericiler sadece bir projenin ne kadar inşa edilebilir olduğunu değil, aynı zamanda neden inşa edilemediğini de bilmek isterler. Ancak ANN'ler dezavantajları nedeniyle bu soruyu cevaplamakta yetersiz kalmaktadır. 1965 yılında Zadeh tarafından ortaya konan bulanık küme teorileri, kötü yapılandırılmış tasarım ve inşaat problemlerinin yanı sıra inşa edilebilirlik problemlerini de çözmek için yaygın olarak kullanılmaktadır (Quing, 2004). Keskenler ve Keskenler (2017)'e göre Zadeh'in Bulanık Mantık ilkeleri şu şekildedir:

- Bulanık mantık yönteminde kesin belli olan değerler yerine yaklaşık değerler kullanılır.

- Bulanık mantık yönteminde için bilgi çok az, az, küçük, büyük şeklinde dilsel ifadeler ile tanımlanır.

- Bulanık mantık yönteminde tüm değerler [0-1] aralığında bir üyelik derecesi ile gösterilir.

- Her mantıksal ifade bulanık halde ifadeye dönüştürülebilir.

1996 yılında Malek proje yönetiminde en uygun inşaat yöntemini seçmek için bulanık mantık ile bir inşa edilebilirlik değerlendirme modeli geliştirmiştir. Chao ve Skibniewski 1998 yılında, yeni inşaat teknolojisini değerlendirmek için bulanık mantık tabanlı risk içeren bir yaklaşım geliştirmiştir. Genel olarak bulanık yöntem, inşa edilebilirlik gözden geçirmeleri ve değerlendirmeleri için uygun ve umut verici bir yaklaşımdır ve resmi inşa edilebilirlik değerlendirmesi için bir yöntem geliştirme de kullanılabilmektedir (Barai ve Nair, 2004; Quing, 2004).

BAM İnşa Edilebilirlik Değerlendirme Modelinin geliştirilmesi çalışmaları ise 2003 yılında başlatılmıştır. Bu çalışma kapsamında Hong Kong'daki müteahhit inşaat firmaları ile bir dizi görüşme yapılmış ve anketler uygulanmıştır. Bu çalışmalarda, bina tasarımlarının inşa edilebilirliğini ölçmek için inşa edilebilirlik indeksi (BIs) ve inşa edilebilirlik ağılıklarını (BWs) belirlemek amaçlanmıştır. İnşa edilebilirlik indeksi; bireysel tasarım öğelerinin göreceli olarak oluşturulabilirliğini temsil ederken, inşa edilebilirlik ağırıkları; taşıyıcı çerçeve sistemleri, döşeme sistemleri, kabuk sistemleri, çatı sistemleri, diğer yapısal sistemler ve şantiye alanı faktörlerini kapsamaktadır (Lam ve Wong, 2009). BAM'a göre toplam inşa edilebilirlik puanlarının hesaplanması, üç farklı tasarım bileşenine göre değerlendirilmektedir: 
(1) Yapım sistemleri

(i) Taşıyıcı sistemler

(ii) Döşeme sistemleri

(iii) Yapı kabuğu sistemleri

(iv) Çatı sistemleri

(2) Diğer inşa edilebilir özellikler (iç duvar sistemleri, yüzey bitiş sistemleri, servis sistemleri, yapı özellikleri)

(3) Şantiye alanı ile ilgili faktörler

Tasarım bileşenlerinin her biri için, farklı tasarım bileşenleri arasındaki nispi önem ağırlı̆ını temsil eden katsayı, deneyimli 99 uygulayııı firma ile yapılan anket çalışması sonucunda elde edilen bulgulardan ayarlanarak belirlenmiştir. Örneğin; taşıyıcı çerçeveler için bu katsayı katsayısı 100 üzerinden 23'tür. İnşa edilebilirlik puanı (BScore) yapının inşa edilebilirliğini ifade etmektedir. BScore, yukarıdaki üç tasarım bileşeninden elde edilen puanların toplamından oluşur. Ayrıca; BAM kapsamına girmeyen, inşa edilebilirliği geliştirmeye yönelik yenilikçi fikirler için bir ilave puanı da verilmektedir. Bu puan, tasarım ekibinin BAM yöntemi ile büyük ölçüde objektif bir değerlendirme dahilinde inşa edilebilirlik dereceleri belirlenebilmektedir. Tasarımın inşa edilebilirliğini değerlendirmek için BAM kullanımı, tasarımcıları tasarım aşamasında inşaat zorluklarını dikkate almalarının önemi konusunda uyarmaktadır. Buna ek olarak, BAM inşa edilebilirliği nesnel ve açık bir temelde ölçtüğü için, tutarlı yorumlar mümkün olurken, alternatif tasarımlardaki inşa edilebilirlik seviyeleri de karşılaştırılabilmektedir (Lam ve Wong, 2008).

İnşa Edilebilir Tasarım Değerlendirme Sistemlerinden bir başkası da BDAS'dir. Bu sistem, bir bina tasarımının, şantiye alanında kullanılan iş gücü (iş̧̧i) üzerindeki potansiyel etkisini ölçmek için Singapur Yapı ve İnşaat Kurumu (BCA) tarafından geliştirilmiştir. BDAS Değerlendirme Sistemi, tasarımların inşa edilebilir tasarım puanının belirlenmesini amaçlamaktadır. Daha yüksek inşa edilebilir tasarım puanına sahip bir tasarım, yapım sürecinde daha verimli iş gücü kullanımı ve verimli üretim ile sonuçlanmaktadır (BCA, 2000).

BDAS'ın kullanım amacı, inşa edilebilir tasarımların yaygınlaşmasını sağlamaktır. Değerlendirme sisteminde kullanıcıların intiyaçlarını karşılamak için daha fazla çeşitlilik ve mimari özelliklere ihtiyaç olduğu kabul edilmektedir (BCA, 2017). Singapur'da 2001 yılından itibaren, dini binalar gibi muaf bina türleri hariç diğer tüm bina planlarının Yapı ve İnşaat Kurumu (BCA) tarafından onaylanmadan önce BDAS ile hesaplanan en az inşa edilebilir tasarım puanlarına ulaşması istenmiştir. BDAS bina planlarının inşa edilebilirliğini 3 açıdan değerlendirmektedir:

(1) Çatı sistemleri de dâhil olmak üzere yapısal sistemler

(2) Duvar sistemleri

(3) Diğer inşa edilebilir tasarım özellikleri, örneğin; standardizasyon, modüler boyutlar ve prekast veya prefabrik bileşenlerin kullanımı.

Ayrıca; prefabrike banyo veya tuvalet üniteleri ve sığınaklar gibi tekil entegre bileşenlerin kullanımı için ek puanlar verilmektedir (Lam vd., 2008). BDAS'de yalnızca prefabrikasyonu teşvik etmek amaçlanmamaktadır. Her ne kadar, genel olarak, prefabrikasyon tasarımın daha yüksek inşa edilebilir tasarım puanı almasına neden olsa da yerinde dökme konstrüksiyon kullanan tasarımlar da oldukça yüksek inşa edilebilir tasarım puanı alabilmektedir. BDAS'nin en önemli faydası inşa edilebilir tasarımlar sayesinde, kalite konusunda iyileşmelere yol açmasıdır (BCA, 2017).

CAS İnşa Edilebilirlik Değerlendirme Sistemi de yine Singapur'da geliştirilen bir sistemdir. Amacl; şantiyede insan gücü talebini azaltmaya yardımcı olabilecek emek tasarrufu sağlayan inşaat yöntemleri ve teknolojilerinin daha çok kullanımını sağlamaktır. BDAS, tasarım süreci sırasında inşa edilebilir yapım yöntemlerinin kullanımına odaklanırken; CAS, daha fazla verimlilik sağlamak için, inşaat yöntemlerindeki iyileştirmeleri teşvik eder. Tasarımcıların inşa edilebilir tasarımları gerçekleştirme çabası, yapımda müteahhitlerin emek açısından verimli inşaat teknolojilerini benimsemesi ile tamamlandığında yüksek inşa edilebilirlik derecelerine ulaşılabilmektedir. CAS İnşa Edilebilirlik Değerlendirme Sistemi, yapım aşamasında kullanılan inşaat yöntemlerini etkilemektedir. CAS, inşaatçıların inşa edilebilirlik gereksinimini karşılamak için en uygun maliyetli çözümü 
benimsemelerini sağlayan esnek özelliklere sahip performans temelli bir sistemdir. İnşaat işlerinin inşa edilebilirliği; yapısal işler, mimari, mekanik, elektrik ve sıhhi tesisat (AMEP) işleri ile şantiye uygulamaları alanlarında değerlendirilmektedir. Yapısal işler, inşaat projeleri için en çok insan gücü kullanımını gerektirdiğinden, yapısal işler için emeğin verimli kullanıldığı bir inşaat sistemine geçmek, şantiye verimliliğinde doğrudan bir iyileşme sağlamaktadır. Yapısal işlerin yanı sıra müteahhitler; mimari, mekanik, elektrik ve sıhhi tesisat işlerinde de iş gücü kullanımını azaltan verimli inşaat yöntemleri ve teknolojilerinin daha fazla kullanımını benimserlerse, şantiye de verimlilik kazanımları elde edilmektedir. Puanlar, uygulanan inşaat yöntemleri, teknolojileri ve süreçleri esas alınarak verilmektedir. İnsan gücü kullanımını azaltabilen ve şantiye verimliliğini artırabilen yenilikçi inşaat teknolojileri, yöntemleri, sistemleri ve gelişmiş ekipman kullanımına da puan verilerek ödüllendirilmektedir. Verilen puanlar toplanarak "inşa edilebilirlik puanı" elde edilmektedir (BCA, 2011).

\section{Bulgular ve Değerlendirme}

Çalışmanın bu bölümünde inşa edilebilirlik değerlendirme sistemleri içerisinde güncelliğini koruyan, halen Singapur'da uygulanmakta olan BDAS İnşa Edilebilirlik Tasarım Değerlendirme Sistemi ve CAS Inşa Edilebilirlik Değerlendirme Sisteminin karşılaştırılması hedeflenmiştir. İnşa edilebilirlik değerlendirme sistemlerinin karşılaştırılmasında, son dönemde kentlerde yaygın olarak inşa edilen, nokta blok, dört daireli, standart 3 veya 4 oda, bir salon planına sahip tekil konut projeleri dikkate alınmıştır. Bu tercihin sebebi, bu tipte projelerin kentlerde yaşayan orta ve üstü gelir grubundaki aileler tarafından talep görmesi ve özellikle kentsel dönüşüm bağlamında benzer projelerin değişik kat yüksekliklerinde olmak üzere gerçekleştiriliyor olmasıdır. Seçilen proje Konya ili Selçuklu ilçesinde 20221 numaralı ada ve 2 numaralı parsele kayıtlı, $1667 \mathrm{~m}^{2}$ alana sahip arsa için tasarlanmıştır. 1 bodrum, 1 zemin ve 3 normal kattan oluşan parselinde tek blok olarak bulunan bir binadır. Binanın her katında 4 daire olmak üzere toplamda 16 daire bulunmaktadır. Zemin katta bir daire $3+1$ plan tipine sahipken diğer 15 daire $4+1$ ve aynı plan düzenindedir. Bodrum katta, 16 dairenin her birine ait depo, makine dairesi, enerji odası, kazan dairesi, su deposu-arıtma-hidrofor odası ve sığınak bulunmaktadır. Döşeme üstünden döşeme üstüne kat yüksekliği $3 \mathrm{~m}$ 'dir. Bodrum katın tüm dış duvarları betonarme perde duvardır. Projenin taşıyıcı sistemi kolon, kirişli betonarme iskelet sistemdir. Çatı \%30 eğimli, ahşap çatıdır. Zemin katta bulunan 3+1 dairenin brüt alanı (balkon dâhil) $141,71 \mathrm{~m}^{2 \prime}$ dir. 4+1 dairelerin brüt alanı (balkon dâhil) 178,46 m²'dir (Şekil1).

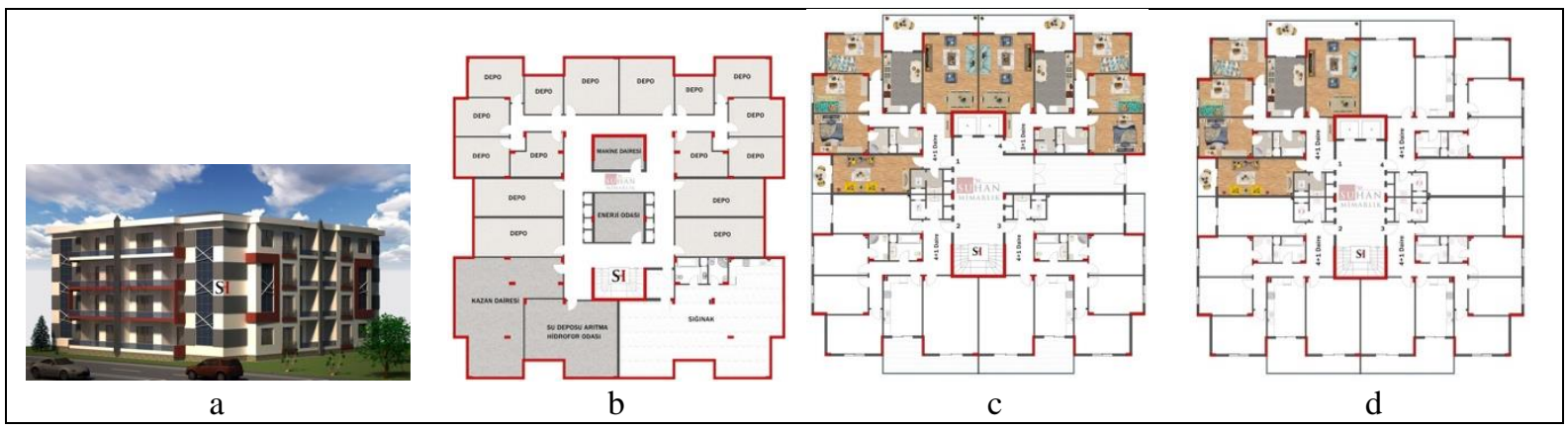

Şekil 1. (a) Projenin genel görünümü (b) bodrum kat planı, (c) zemin kat planı, (d) birinci kat planı (Mimari proje: Y. Mimar Suna Kaya)

\subsection{BDAS inşa edilebilir tasarım değerlendirme sistemi uygulaması}

BDSA'ya göre projelerde tasarımcı öncelikle toprak durumu, şantiye alanındaki erişim, depolama, kaynakların kullanılabilirliği, yetenekler ve teknoloji işlemleri gibi faktörleri göz önünde bulundururarak en uygun yapı sistemini belirlemelidir. Daha sonra BDAS'ta tanımlanan üç temel prensip olan standardizasyon, basitlik ve tekil entegre bileşenlerin kullanımı ile ilkelerin projeye adaptasyonu sağlanmalıdır. BDAS değerlendirme sistemine göre bir tasarımın inşa edilebilir tasarım puanı (Çizelge 2), üç bileşenden elde edilen puanların toplamı ile hesaplanır. Bunlar; taşıyıcı sistem, duvar sistemi ve imalat ve montaj (DfMA) teknolojileri puanlarıdır. İş̧a Edilebilir Tasarım Puanı hesaplanmasına ait formül, semboller, puan aralıkları ve ek puanlarla ilgili açıklamalar Çizelge 3'te özet olarak verilmiştir (BCA, 2017). 
Çizelge 2. Tüm üstyapı yeni projeler için minimum inşa edilebilir tasarım puanı (BCA, 2017)

\begin{tabular}{lccc}
\hline Yapının Kategorisi & \multicolumn{3}{c}{ Üst Yapı İşleri İçin Minimum Inşa Edilebilir Tasarım Puanı } \\
\cline { 2 - 4 } & $2000 \mathrm{~m}^{2} \leq \mathrm{GFA}<5000 \mathrm{~m}^{2}$ & $5000 \mathrm{~m}^{2} \leq \mathrm{GFA}<25000 \mathrm{~m}^{2}$ & $\mathrm{GFA} \geq 25000 \mathrm{~m}^{2}$ \\
\hline Konut (müstakil) & 73 & 78 & 81 \\
Konut (müstakil olmayan) & 80 & 85 & 88 \\
Ticari & 82 & 87 & 90 \\
Sanayi & 82 & 87 & 90 \\
Okul & 77 & 82 & 85 \\
Kurumsal vd. & 73 & 79 & 82 \\
\hline
\end{tabular}

Çizelge 3. Örnek proje için inşa edilebilir tasarım puanı (BDAS) hesabı (Tüm formüller için gerekli değerler BCA 2017'den alınmıştır.) (BCA, 2017)

\section{PUAN HESABI}

Hesaplama yöntemi:

$\left\{45\left[\Sigma\left(A_{s} \times S_{s}\right)\right]+\right.$ Taşıyıcı Sistem

Özellikleri Ek Puanı*\}

\section{Semboller:}

As = Asa / Ast

As = Belirli bir yapısal sistemi kullanan

toplam kat alanı yüzdesi

Ast = Toplam zemin alanı (bodrum

alanı ve çatının planlanmış alanları

dahil)

Asa = Belirli bir taşıyıcı sistemin

kullanıldığı yüzey alanı

Ss = Yapısal sistem için iş gücü tasarruf

endeksi (LSI)

Ek Puan Açıklamaları:

- Taşıyıcı sistem ek puan

Standart kolonlar ve kirişler, planın

dikey tekrarı, prefabrik MEP

yükselticileri gibi özelliklerin

kullanımına verilen ekstra puanlar

* En fazla 5 puan

\section{ÖRNEK PROJE PUAN HESABI}

Toplam döşeme alanı:

$A_{s t}=3590,326 m^{2}+67,20 m^{2}+778,762 m^{2}+696,76 m^{2}=5133,048 m^{2}$

Betonarme Taşıyıcı Sistem:

Toplam kat alanının \%85'i çerçeve kirişli düz plak döşeme, kiriş derinliği $\leq 600 \mathrm{~mm}$ 'dir.

$A_{s a}=4354,286 m^{2} \quad A_{s t}=5133,048 m^{2}$

$A_{s}=A_{s a} / A_{s t}=4354,286 \mathrm{~m}^{2} / 5133,048 \mathrm{~m}^{2}=0,85^{\prime} \mathrm{dir}$

$\mathrm{S}_{\mathrm{s}}=0,85^{\prime}$ dir.

$45 \times$ (As $\times$ Ss) $=45 \times(0,85 \times 0,85)=\mathbf{3 2 , 5 1 3}$ puan

Çatı Sistemi:

Çatı alanı $A_{s a}=778,762 \mathrm{~m}^{2}$

$A_{s}=A_{s a} / A_{s t}=778,762 \mathrm{~m}^{2} / 5133,048 \mathrm{~m}^{2}=0,15$

$\mathrm{S}_{\mathrm{s}}=0,75.45 \times\left(\mathrm{A}_{\mathrm{s}} \times \mathrm{S}_{\mathrm{s}}\right)=45 \times(0,15 \times 0,75)=\mathbf{5 , 0 6 3}$ puan

Ek Puanlar:

- Zorunlu maddeler: Prekast ev sığınakları = 1 puan

- Standardizasyon ve tekrarlama

Kolonların 50 mm'nin katları olması = 2 puan

Kirişlerin 50 mm'nin katları olması $=\mathbf{2}$ puan

Taşıyıcı zemin döşemenin dikey tekrarı =1 puan

- Diğer taşıyıcı sistem ile ilgili inşa edilebilir özellikler

Yüksek dayanımlı beton kullanımı = 1 puan

Diyafram duvarı (bodrum kalıcı istinat duvarı) $=\mathbf{2}$ puan

- B başlıkata fazla puan BCA tarafından $\mathbf{5}$ puan ile sınırlandırılmıştır.

\section{$32,513+5,063+5=42,576=43$ PUAN}

TOPLAM ( $\leq 45$ puan)

Giydirme Cephe Duvar Sistemi:

$\left\{40\left[\Sigma\left(L_{w} x S_{w}\right)\right]+C+\right.$ Mimari Özellikler Ek

Puanı $\}^{* *}+$ Uyarı Puanları

Semboller:

$L_{w}=L_{w a} / L_{w t}$

$\mathrm{L}_{w}=$ Belirli bir duvar sisteminin

kullanıldığı toplam iç ve dış duvar uzunluklarının yüzdesi

$\mathrm{L}_{\mathrm{wt}}=$ Toplam iç ve dış duvar uzunluğu

(toprak altında kalan bodrum kat dış duvarları hariç)

$\mathrm{L}_{w a}=$ Belirli bir duvar sisteminin

kullanıldığı iç ve dış duvarların

uzunluğu

$\mathrm{S}_{\mathrm{w}}=\mathrm{i}$ ç ve dış duvar sistemleri için iş

gücü tasarruf endeksi (LSI)

$\mathrm{C}=$ Basit (sade) tasarımlar için ek

puanlar

Ek Puan Açıklamaları:

- Mimari özellikler ek puanları Hem proje hem de endüstri seviyesindeki standart bileşenler/ tasarım parametreleri gibi inşa edilebilir özelliklerin (belirli geliştirme tipleri için zorunlu ürünler dâhil), prefabrik duvarlar / ıslak alanlar için alçı levha ve ahşap döşeme gibi inşa edilebilir tasarımların kullanımı için verilen puanlar.
$185 \mathrm{~cm}$, $\mathrm{L}_{\text {wa }}=2880 \mathrm{~cm}, \mathrm{~S}_{\mathrm{w}}=1,00, \mathrm{~L}_{\mathrm{w}}=\mathrm{L}_{\mathrm{wa}} / \mathrm{L}_{\mathrm{wt}}$

$\mathrm{L}_{\mathrm{w}}=2880 \mathrm{~cm} / 228185 \mathrm{~cm}=0,013=\% 1,3$

$40 \times(0,013 \times 1)=\mathbf{0 , 5 2}$ puan

Yerinde Dökme İnce Yüzey Bitişli Betonarme Duvar ve Kolonlar:

$\mathrm{L}_{w t}=228185 \mathrm{~cm}, \mathrm{~L}_{\mathrm{wa}}=34940 \mathrm{~cm}, \mathrm{~S}_{\mathrm{w}}=0,80$

$L_{w}=L_{w a} / L_{w t}: L_{w}=34940 \mathrm{~cm} / 228185 \mathrm{~cm}=0,153=\% 15,3$

$40 \times(0,153 \times 0,80)=4,9$ puan

Standart Bloklarla Örülmüş Ince Yüzey Bitişli Örme Duvar Sistemi:

$\mathrm{L}_{\mathrm{wt}}=228185 \mathrm{~cm}, \mathrm{~L}_{\mathrm{wa}}=190365 \mathrm{~cm}, \mathrm{~S}_{\mathrm{w}}=0,30$

$\mathrm{L}_{w}=\mathrm{L}_{w a} / \mathrm{L}_{w t}: \mathrm{L}_{w}=190365 \mathrm{~cm} / 228185 \mathrm{~cm}=0,834=\% 83,4$

$40 \times(0,834 \times 0,30)=10,008$ puan

Basit (sade) Tasarımlar İçin Ek Puanlar (C):

- Yüksek Boşluk Yüzdesi): \%0 (yüksek boşluk yok) = 2 puan

- Karmaşık Formu Olmayan Tasarımlar İçin Puanlar:

Basit geometrik form ve bina yüksekliğinin $15 \mathrm{~m}$ ile $45 \mathrm{~m}$ arasında olması $=\mathbf{3}$ puan

- $\mathrm{C}=$ Basit (Sade) tasarımlar için ek puanlar $=2+3=5$ puandır.

Mimari Özellikler Ek Puanı:

- Zorunlu Öğeler

65 adet $80 \mathrm{~cm}, 22$ adet $100 \mathrm{~cm}, 113$ adet $90 \mathrm{~cm}, 15$ adet $150 \mathrm{~cm}$ sürgülü, 32 adet $200 \mathrm{~cm}$ sürgülü kapı ve 2 adet $200 \mathrm{~cm}$ genişliğinde dış kapı vardır. BCA (2017)’ye göre $90 \mathrm{~cm}, 100 \mathrm{~cm}, 150 \mathrm{~cm}$ ve $200 \mathrm{~cm}$ genişliğindeki kapılar standart sayılmaktadır. Toplam kapı sayısına göre standart kapılar 184 / $249=\% 74$ 'ünü oluşturmaktadır. Standart kapı açıklıkları (genişlik) = 0,50 puan

- Standardizasyon ve Tekrarlama Pencereler (genişlik ve yüksekliği $10 \mathrm{~cm}$ 'nin katları) $=\mathbf{0 , 7 5}$ puan Döşemeden döşemeye kadar olan yüksekliğin $300 \mathrm{~cm} ; 50 \mathrm{~mm}$ katı = 1 puan

- Diğer İnşa Edilebilir Mimari Özellikler: Endüstri standardı kapı açıklıkları = 0,50 puan

- Hata (Uyarı) Puanları: Tuğla duvar / blok duvar kullanıldığı için puan kesintisi = -3 puan

- Mimari Özellikler Ek Puanı: 0,50+0,75+1+0,50-3 $=-\mathbf{0 , 2 5}$ puan 


\begin{tabular}{|c|c|c|}
\hline \multirow[t]{2}{*}{ 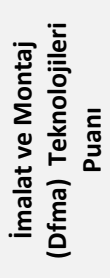 } & $\begin{array}{l}\text { N } \\
\text { Açıklamalar: } \\
\text { Bu bölümde imalat ve montaj } \\
\text { teknolojileri için tasarım sürecinde; } \\
\text { yapısal, mimari, elektrik, mekanik ve } \\
\text { sıhhi tesisat (MEP) için puanlar BCA } \\
\text { 2017'ye göre verilir. }\end{array}$ & $\begin{array}{l}\text { Yenilikçi bağlantılara sahip yapısal çelik elemanlar kullanılması =6 puan } \\
\text { Mekanik, Elektrik ve Tesisat (MEP) döşeme sistemi = } \mathbf{6} \text { puan } \\
\text { Yerinde kuru uygulanan kaplamalı prefabrike tavan =1 puan } \\
\text { Esnek yağmurlama damlalığı = } \mathbf{1} \text { puan } \\
\text { Esnek su boruları = } \mathbf{1} \text { puan }\end{array}$ \\
\hline & TOPLAM ( $\leq 20$ puan) & $6+6+1+1+1=15$ PUAN \\
\hline & $\begin{array}{l}\text { Toplam İnşa Edilebilir Tasarım Puanı } \\
\text { (BDAS) }\end{array}$ & $\begin{array}{l}\text { Taşıyıcı Sistem Puanı + Duvar Sistemleri Puanı + İmalat ve Montaj Teknolojileri Puanı } \\
43+20+15=78 \text { PUAN }\end{array}$ \\
\hline
\end{tabular}

Örnek Projenin BDAS sistemi le puanlarının hesaplanması Singapur'un ulusal planlama otoritesi olan Kentsel Yeniden Geliştirme Kurumu'nun (URA: The Urban Redevelopment Authority) yayınladığı Toplam Kat Alanı El Kitabına (URA, 2019) göre yapılmıştır. Buna göre, projenin toplam kat alanı (GFA): 3590,326 $\mathrm{m}^{2}$ olarak hesaplanmıştır. Bu hesaplamaya göre örnek proje Tüm Üstyapı Yeni Projeler için En az (Toplam) İnşa Edilebilir Tasarım Puanı Çizelgesi'ne göre GFA(1) Müstakil Olmayan Konut kategorisine girmekte ve tasarımın inşa edilebilirlik değerlendirmesinden olumlu değerlendirme alabilmesi için,toplam en az 80 puan alması gereklidir (Çizelge 2). Bu hesaplamadan alınabilecek en fazla puan ise $110^{\prime}$ dur.

Örnek projenin İnşa Edilebilir Tasarım Puanı hesabı Çizelge 3'te verilmiştir. Taşıyıcı sistemin inşa edilebilir tasarım puanı hesabında, taşıyıcı sistem elemanlarının kapladığı alanının yüzdesi ve iş gücü tasarruf endeksi değerinin toplamı ile oluşturulmuştur. Il gili değerler Singapur Yapı ve İnşaat Kurumu'nun İnşa Edilebilir Tasarım Uygulama Yönetmeliği'nde yer almaktadır (BCA, 2017). Örnek projenin puanının hesaplanmasında Çizelge 3'te yer alan formüllerde kullanılacak değerler de bu yönetmelikten elde edilmiştir (BCA, 2017). Uygulanan farklı yapı sistemleri ve prefabrik donatı kullanımı için inşa edilebilir tasarım puanları, çeşitli yapı sistemlerinin ve prefabrik donatıların inşa edilebilir tasarım puanına ulaşmak için ağırlık faktörü ile toplanır ve çarpılır. Taşıyıcı sistemin inşa edilebilir tasarım puanı hesabında, arsası olmayan konut projeleri için zorunlu olan prefabrike yapı özelliklerinin kullanımını teşvik etmek ilave puanlar alınabilmektedir. Bileşenlerin standardizasyonu, düzen tekrarı ve üretken teknolojilerin kullanımı için ek puan verilir (BCA, 2017). Buna göre örnek proje taşıyıcı sistem başlığından 43 puan almıştır. Projenin taşıyıcı sistem başlığından aldığı puanlar ağırlıkı olarak seçilen betonarme iskelet sistemden kaynaklanmaktadır. Projenin basit ve tekrarlayan açıklık düzeni ve karmaşık olmayan tasarımı hızlı inşa edilmesini sağlamaktadır. Benzer şekilde, tekrarlanan boyutlarda kolonlar veya dış kaplamalar, şantiye alanında veya fabrikada, kalıp değişikliği sayısını azaltacaktır. Basitlik, karmaşık olmayan bina yapım sistemlerini ve montaj detaylarını içerir. Örneğin projede düz plak döşeme sistemi kullanılması kalıp işlerini büyük ölçüde kolaylaştıracaktır. Ayrıca kullanılan ahşap çatı sistemi ve çatı tasarımı da karmaşık olmayan bir yapıya sahiptir. Projenin taşıyıcı sistemden aldığı ek puanlar ise kolon ve kiriş boyutlarının 50 mm'nin katlarında ve tekrarlanıyor olması, taşıyıcı döşeme alanlarının boyut ve biçim olarak her katta aynı şekilde tekrarlanıyor olması, yüksek dayanımlı beton kullanımı ve istinat duvarları başlıklarından gelen 5 puandır. Böylece, örnek proje bu bölümden alınabilecek en fazla 45 puana yakın bir puana $(42,576=$ 43) ulaşabilmiştir (Çizelge 3).

Belirli bir duvar sistemi için inşa edilebilir tasarım puanı ise, duvar sistemi tarafından kapsanan duvar uzunluğu yüzdesi ile ilgili iş gücü tasarruf endeksi çarpılarak hesaplanır (Çizelge 3). Farklı duvar sistemleri için inşa edilebilir tasarım puanları daha sonra toplanır ve ağılık faktörü ile çarpılır. Bu kapsamda, konut projelerinde tüm iç duvarlar için (prefabrike duvarı / tuvalet duvarı / mutfak duvarı hariç) alçıpan kullanımı zorunludur. Buna ilaveten, basit ve karmaşık biçimlerde olmatan tasarımlar için teşvik amaçlı 5 puan ek olarak verilmektedir. Duvar sistemi puanlamasında, boyutsal ve detaylandırma açısından standardize edilmiş bileşenlerin ve tasarım parametrelerinin kullanımı, boyutsal ızgaraların tekrarlanması ve kuru bağlantıların kullanımı teşvik edilmektedir. Duvar sistemleri bölümünden alınabilecek en fazla inşa edilebilir tasarım puanı da 45'tir (BCA, 2017). Örnek proje duvar sistemleri başlığından 20 puan almıştır. Projenin aldığı puanlar cephede karmaşık olamayan, tekrarlayan form ve detayların tercih edilmesi, standart yapısal açıklıklar ve pencere boşlukları gibi unsurlardan kaynaklanmaktadır. Ancak proje bu başlıktan alınabilecek en fazla puan olan 45 puanın yarısını bile sağlayamamaktadır. Burada cephe tasarımında prefabrike yapı 
elemanlarının kullanılmaması olumsuz biz özellik olarak puanlamaya yansımaktadır (Çizelge 3).

Imalat ve montaj (DfMA) teknolojileri puanı yapısal, mimari, elektrik, mekanik ve sıhhi tesisat (MEP) disiplinlerinde kullanılan çeşitli teknolojilere dayalı olarak verilir (Çizelge 3). DfMA teknolojileri, potansiyel insan gücü tasarruflarını ayırt etmek için prefabrike bileşenler, gelişmiş prefabrike sistemler, tamamen entegre alt montajlardan tamamen entegre sistemlere kadar farklı sınıflara ayrılmıştır. Bu teknolojilerinin kullanımı puanla ödüllendirilmektedir (BCA, 2017). Bu bölümde imalat ve montaj teknolojileri için tasarım sürecinde; yapısal, mimari, elektrik, mekanik ve sıhhi tesisat (MEP) disiplinlerinde kullanılan çeşitli teknolojiler için puan verilmiştir (BCA, 2017). Örnek projenin puanları; yenilikçi bağlantılara sahip yapısal çelik elemanlar kullanılması 6 puan, mekanik, elektrik ve tesisat (MEP) döşeme sistemi uygulamasından 6 puan, yerinde kuru uygulanan kaplamalı prefabrike tavan uygulamasından 1 puan, esnek yağmurlama damlalığı 1 puan, esnek su boruları 1 puan olmak üzere ilgili tablolardan belirlenmiştir (BCA, 2017). Örnek proje en fazla 20 puan alınabilen imalat ve montaj teknolojileri başlığından 15 puan almıştır. Projenin aldığı toplam İnşa Edilebilir Tasarım Puanı ise 78 olarak bulunmuştur. Buna göre BDAS kriterlerine göre alması gereken en az puan olan 80 puana ulaşamamıştır (Çizelge 3).

\subsection{CAS inşa edilebilirlik değerlendirme sistemi uygulaması}

Inş̧a Edilebilirlik Değerlendirme Sistemi (CAS), Singapur Yapı ve İnşaat Kurumu tarafından, kullanılan yapım yöntemleri ve teknolojilerinin şantiye de verimlilik üzerindeki potansiyel etkisini ölçmenin bir yolu olarak geliştirilmiştir. CAS, yapı çalışmaları "inşa edilebilirlik puanı" ile sonuçlanır. Daha yüksek inşa edilebilirlik puanına sahip bir proje, daha fazla emek verimliliği sağlayan inşaat yöntemleri ve teknolojilerinin kullanılmasına ve dolayısıyla saha emek verimliliğinin artırılmasına neden olacaktır. En

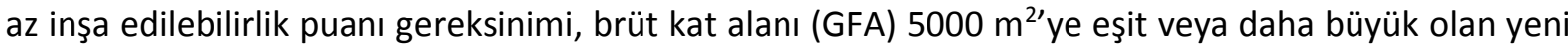
projeler ile mevcut binada onarım, değişiklik ve ilavelerden oluşan projeler için geçerlidir (Çizelge 4). CAS değerlendirme sistemine göre bir tasarımın inşa edilebilir tasarım puanı, üç bileşenden elde edilen puanların toplamı ile hesaplanır. Bunlar; yapı sistemi, mimari, mekanik, elektrik ve tesisat (AMEP) sistemi ve İyi endüstri uygulamaları puanlarıdır. İnşa Edilebilirlik Puanı (CAS) hesaplanmasına ait formül, semboller, puan aralıkları ve ek puanlarla ilgili açıklamalar Çizelge $5^{\prime}$ de özet olarak verilmiştir. Toplam inşa edilebilirlik puanı en fazla 120'dir (BCA, 2017).

Çizelge 4. Tüm üstyapı yeni projeler için minimum inşa edilebilirlik puanı (BCA, 2017)

\begin{tabular}{|c|c|c|}
\hline \multirow{2}{*}{ Yapının Kategorisi } & \multicolumn{2}{|c|}{ Üst Yapı İşleri İçin Minimum İnşa Edilebilir Tasarım Puanı } \\
\hline & $5000 \mathrm{~m}^{2} \leq \mathrm{GFA}<25000 \mathrm{~m}^{2}$ & GFA $\geq 25000 \mathrm{~m}^{2}$ \\
\hline \multicolumn{3}{|c|}{ Konut (müstakil) } \\
\hline \multicolumn{3}{|c|}{ Konut (müstakil olmayan) } \\
\hline Ticari & \multirow{4}{*}{$\begin{array}{c}50 \\
\text { (yapısal sistemden en az } 35 \text { puan) }\end{array}$} & \multirow{4}{*}{$\begin{array}{c}60 \\
\text { (yapısal sistemden en az } 45 \text { puan) }\end{array}$} \\
\hline Sanayi & & \\
\hline Okul & & \\
\hline Kurumsal vd. & & \\
\hline
\end{tabular}

Yapı sisteminde inşa edilebilirliğe ulaşmak için için en pratik ve uygun maliyetli yaklaşımlarını teşvik etmeye yönelik puanlar verilmektedir. Harici erişim sistemleri olarak adlandırılan iskele sistemleri ve kalıp sistemleri bu puanlamada dikkate alınır. Puan hesabı bina çevre uzunluğu ve kalıp alan yüzdesine göre belirlenir. Ayrıca yapı sisteminde kullanılan yenilikçi sistemler de puan verilmektedir. Yenilikçi sistemlerin özellikle işgücü kullanımı üzerindeki etkileri değerlendirilmekte ve BCA (2017)'ye göre puanlandırılmaktadır. Yapı sistemine ait puanlar ve hesaplama yöntemleri Çizelge 5 'te özetlenmiştir.

Mimari, mekanik, elektrik ve tesisat (AMEP) sisteminin inşa edilebilirlik puanlamasında, özellikle şapsız döşeme ve sıva işi olmayan duvar kullanımı gibi şantiyede ince yapı işlerinin azaltmak teşvik edilmektedir. Puanlamada bu tür uygulamaların döşeme ve duvar alan yüzdeleri dikkate alınmaktadır. Püskürtme boyama, ön yalıtımlı borular, prefabrik ve ön yalıtımlı kanallar, esnek su boruları ve M\&E boruları için mekanik bağlantılar gibi diğer AMEP öğeleri için, ilgili şartlar yerine getirildiğinde bu öğelerin kullanımına doğrudan puanlar verilmektedir. AMEP'in sahada iş gücü tasarrufuna katkı da bulunan yenilikçi yöntem ve sistemlere de inşa edilebilirlik puanları verilmektedir. İyi endüstri uygulamaları için ise, inşaat verimliliğinin artırılmasına yardımcı olan iyi 
endüstri uygulamalarına doğrudan puan verilmektedir (BCA, 2017) (Çizelge 5).

Örnek Projenin CAS sistemi le puanlarının hesaplanması Singapur Yapı ve İnşaat Kurumu yayınladığı EI Kitabına (BCA, 2017) göre yapılmıştır. Projenin toplam inşa edilebilirlik puanı; yapım sistemi, AMEP sistemi ve iyi endüstri uygulamaları için elde edilen inşa edilebilirlik puanların toplanmasıyla elde edilmektedir. Bu üç bileşenden toplam gelecek inşa edilebilirlik puanı maksimum 120dir. Toplam inşa edilebilirlik puanı proje türüne ve $\mathrm{m}^{2}$ sine göre minimum puan şartını sağlamadan onaylanmamaktadır. Örnek proje müstakil olmayan bir konut projesidir ve toplam kat alanı (GFA), 3590,326 $\mathrm{m}^{2 \prime}$ dir. BCA 2017'ye göre bu projenin toplam kat alanı $5000 \mathrm{~m}^{2 \prime}$ den küçük olduğu için minimum inşa edilebilir puanı gerekmemektedir. Ancak inşa edilebilirlik sisteminin (CAS) özelliklerini incelemek için projenin inşa edilebilir puanı hesaplanmıştır. Örnek projenin İnşa Edilebilirlik Puanı hesabı Çizelge 5'te verilmiştir. Buna göre proje yapı sistemi başlığından 26,3, AMEP sistem yapı işleri başlı̆ından 11 ve iyi endüstri uygulamaları başlığından ise 6 puan almıştır. Toplam puan ise 43,3 olarak bulunmuştur.

Çizelge 5. Örnek proje için inşa edilebilirlik puanı (CAS) hesabı (Tüm formüller için gerekli değerler BCA 2017'den alınmıştır) (BCA, 2017)

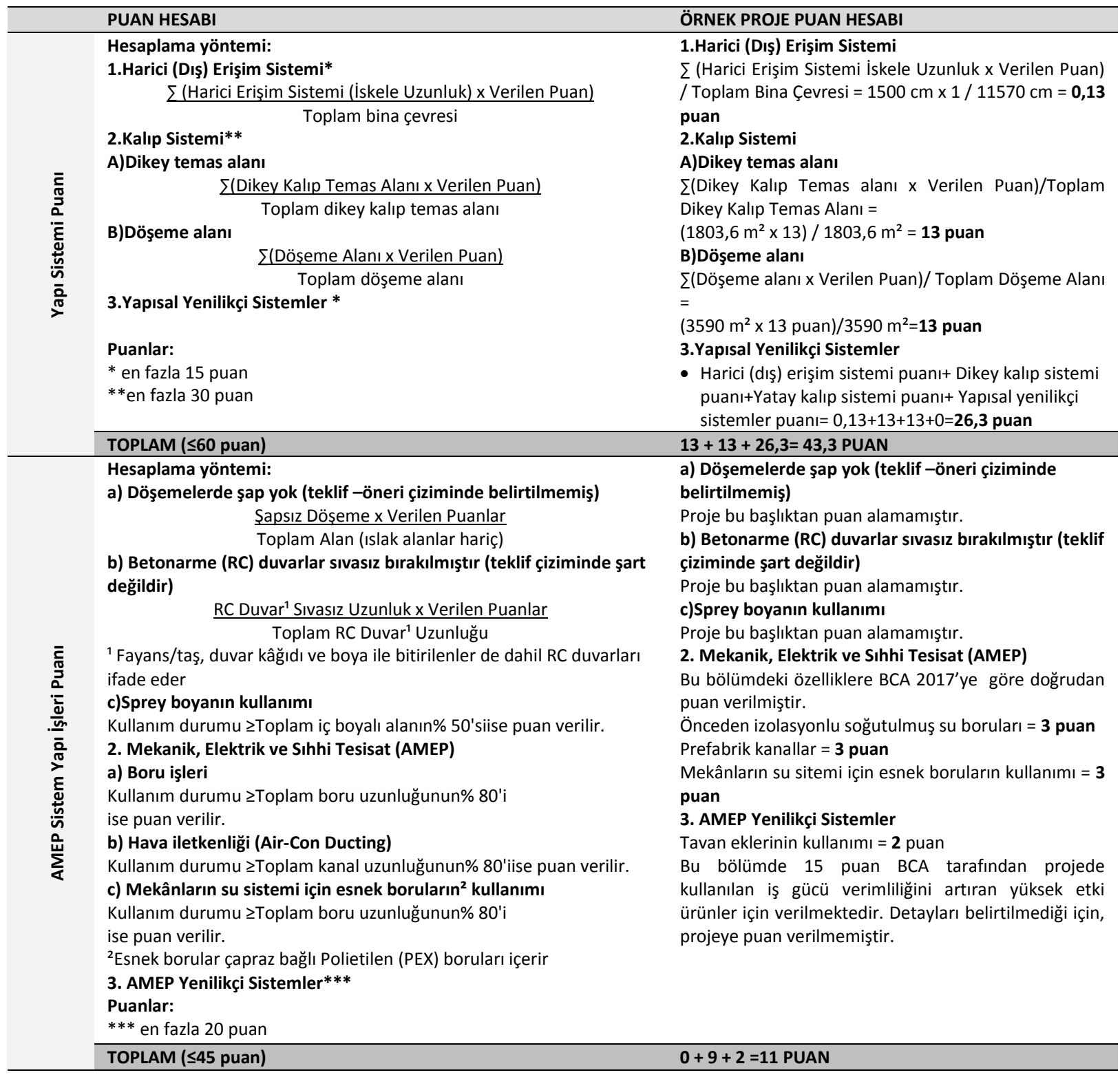




\begin{tabular}{|c|c|c|}
\hline \multirow[t]{3}{*}{ 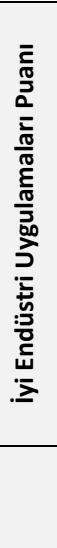 } & $\begin{array}{l}\text { İnşaat verimliliğinin artııılmasına yardımcı olan iyi endüstri } \\
\text { uygulamalarına doğrudan puan verilmektedir. Puanlar BCA 2017'de } \\
\text { tanımlanmıştır. }\end{array}$ & $\begin{array}{l}\text { Bu bölümdeki özellikler BCA 2017'ye göre } \\
\text { puanlandırımıştır. } \\
\text { Mekanik, elektrik proje çizimleri ile mimari çizimler } \\
\text { arasında koordinasyon yapılması; inşaat programları } \\
\text { ve kaynak planlamasının gösterimi = } \mathbf{2} \text { puan } \\
\text { İnşaat sürecinin bir parçası olarak eşzamanlı entegre } \\
\text { mühendislik, süreç ve üretim yönetimi ve ölçülerinin } \\
\text { benimsenmesi = } \mathbf{3} \text { puan } \\
\text { Şantiyede çalışma sürecini incelemek-geliştirmek, } \\
\text { israfı en aza indirmek ve verimliliği artırmak için aylık } \\
\text { iş etüdü oturumları yapılması (Şantiye şefi ve } \\
\text { müteahhit arasında yapılmaktadır.) = 1 puan }\end{array}$ \\
\hline & TOPLAM ( $\leq 15$ puan) & $2+3+1=6$ PUAN \\
\hline & Toplam İnşa Edilebilirlik Puanı (CAS) & 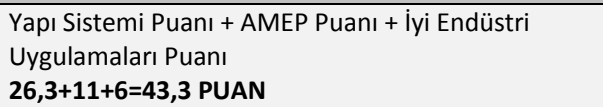 \\
\hline
\end{tabular}

\section{Tartışma ve Sonuç}

Bu çalışmada; İngiltere, Amerika Birleşik Devletleri, Avusturalya, Hong Kong ve Singapur gibi çeşitli ülkelerdeki inşa edilebilirlik ve inşa edilebilirlik değerlendirmelerinin gelişimi gözden geçirilmiştir. Genel proje hedeflerine (kalite, maliyet, süre vs.) ulaşmak için planlama, tasarım ve şantiye uygulamalarında en fazla inşaat bilgisi ve tecrübesinin kullanılması olarak tanımlanabilen inşa edilebilirlikte, bina satın alma süreçlerinin tamamı için alınan kararların proje ve proje hedeflerini gerçekleştirmedeki kaliteyi artırdığı ve yapımını kolaylaştırdığı bilinmektedir. Bu nedenle literatürde yer alan çalışmalarda inşa edilebilirliğin bir binanın tamamlandıktan sonraki süreyi de içeren, tüm yaşam döngüsünü kapsaması gerektiği görüşü savunulmaktadır. Bir binanın inşa edilebilirlik derecesinin belirlenebilmesi için literatürde yedi farklı inşa edilebilirlik değerlendirme yönteminin kullanıldığı belirlenmiştir. Bunlar; Regresyon Analizi Yöntemi, Uzman Sistem Yöntemi, Yapay Sinir Ağı Yöntemi, Bulanık Mantık Yöntemi, BDAS, CAS ve BAM'dır. Bu yöntemlerden Singapur'da 2001 yılında geliştirilmiş olup, kullanılması yasalarla zorunlu tutulan BDAS (Buildable Design Appraisal System) ve 2011 yılında Singapur'da uygulamaya geçirilen CAS (Constructability Appraisal System) en gelişmiş ve güvenilir yöntemler olarak ön plana çıkmaktadır. Bu bağlamda Singapur'da halen proje onaylarında zorunlu bir değerlendirme yöntemi olarak kullanılan her iki inşa edilebilirlik değerlendirmesi yöntemi çalışmada uygulamalı olarak incelenmek üzere seçilmiştir.

Singapur'da kullanılan BDAS ve CAS inşa edilebilirlik değerlendirme yöntemlerinin örnek projeye uygulanması ile karşılaştırılması yapıldı̆̆ında, BDAS'ın tasarım süreci sırasında inşa edilebilir tasarımların kullanımına odaklandığı, CAS'ın ise daha fazla verimlilik sağlamak için, inşaat yöntemlerindeki iyileştirmelerle mücadele ettiği görülmektedir. Tasarımcıların inşa edilebilir tasarımlara gösterdiği özen, inşaatta (yapımda) daha fazla kolaylık sağlamak için müteahhitlerin emek açısından verimli inşaat teknolojilerini benimsemesi ile tamamlanmalıdır. İnşa edilebilirlik amaçları açısından karşılaştırılacak olursa; BDAS sisteminde tasarımın şantiye alanında kullanılan iş gücü (iş̧̧i) üzerindeki potansiyel etkisini ölçmek amacı doğrultusunda, standardizasyon, basitlik ve tekil entegre bileşen kullanımı teşvik edilmekte ve puanla ödüllendirilmektedir. CAS ise kullanılan yapım yöntemleri ve teknolojilerinin şantiye de verimlilik üzerindeki potansiyel etkisini ölçmeyi amaçlar. Her iki sistemin geliştirildiği ve uygulamaya koyulduğu yıllara bakıldığında; 2001 yılında tasarımın iş gücü üzerindeki potansiyel ölçüsünü ölçmenin önemsendiği yaklaşımın, on yıllık bir uygulama süresinden sonra yeterli görülmediği ve yapım yöntemleri, yapı elemanları, bileşenleri ve ince yapı uygulamaları bağlamında değerlendirmelere ihtiyaç olduğu anlaşılmıştır. CAS'ın uygulanmaya başlandığı tarih $2011^{\prime}$ dir. O tarihten bu güne, özellikle yüksek yoğunluklu kent dokusu içindeki $5000 \mathrm{~m}^{2 \prime}$ den büyük yapılarda yapım yöntemleri açısından inşa edilebilirlik değerlendirmesinin zorunlu tutulmuş olması, yapım sürecinde şantiyede verimliliği sağlarken, başka bir bakış açısı ile de yapımda ekonomiyi sağlama ve inşaat sürecinde ortaya çıkabilecek çevresel etkilerin azaltılmasını amacı doğrultusunda gerçekleşmiştir.

BDAS puanları taşıyıcı sistem, duvar sistemi ve malat ve montaj (DFMA) teknolojileri başıklarından alının puanların toplamından; CAS puanları ise yapı sistemi, mimari, mekanik, elektrik ve tesisat (AMEP) sistemi ve iyi endüstri uygulamaları başlıklarından alınan puanların toplamından 
oluşmaktadır. Bu bağlamda örnek proje üzerinden yapılan hesaplamalarda projenin her başlıktan aldığı puanlar aşă̆ıdaki şekilde değerlendirilmektedir.

Proje BDAS puanlamasında en yüksek puanı (43 puan) taşıyıcı sistem başlığından almıştır. Taşıyıcı sistemin basitlik, standardizasyon ve ölçü tekrarı gibi niteliklerinin bulunması bunun nedenidir. Bu nedenle BDAS değerlendirmesinde tasarımcının karmaşık olmayan formları tercih etmesi bi avantaj olarak ön plana çıkmaktadır. Diğer taraftan proje tekil entegre bileşen ve yenilikçi teknoloji kullanımı bağlamında tasarımda bu bileşenlerin kullanımına yönelik bir yaklaşım geliştirilmemiş olması nedeniyle düşük seviyede puan almıştır. Buna karşılık, taşıyıcı sisteme ait değerlendirmeyi de içinde bulunduran CAS yapı sistemi başlığından projenin aldığı puan da 43'tür. Bu başlıktan alınabilecek en fazla puan $60^{\prime}$ tır. Projede, yapı istemi uygulamalarında şantiyede insan gücü talebini azaltmaya yardımcı olabilecek emek tasarrufu sağlayan inşaat yöntemleri ve teknolojilerinin daha çok kullanımını sağlamayı hedeflenmemesi; geleneksel, yoğun emek isteyen inşaat yöntemlerini tercih eden yaklaşımın benimsenmesi olumsuz özellikleri olarak nitelendirilebilir.

Değerlendirme yöntemlerinde yer alan başlıklarda dikkati çeken diğer husus projelerin karşılaması gereken asgari toplam puanların hangi başlıklardan alınabileceğidir. Bu bağlamada her iki değerlendirme yönteminde de taşıyıcı sistem, duvar sistemi ve yapı sistemi başıklarından alınabilecek tam puanlar asgari toplam puana ulaşmada yeterli olmaktadır. Mevcut sistemlerin projelerin inşa edilebilirlik değerlendirmesinde ince yapı işlerinin detaylı bir puanlamaya tabii tutulmadığı bu nedenle puanlamanın inşaatta büyük bir maliyet kalemini ve zaman dilimini kapsayan uygulamaları göz ardı ettiği düşünülmektedir. Örnek projedeki puanlamada da aynı sonuçla karşılaşılmıştır. Toplam puanlar bazında karşılaştırma yapıldığında projenin BDAS'de sağlanması gereken 80 puan, ve CAS' de sağlanması gereken 50 puan bandının aşağısında kaldığı görülmektedir.

Kuşkusuz müşteri katıımıyla tasarım kararları almak, verimli inşaat için tasarımlar yapmak, tasarım ve yapım aşamasında entegrasyon elde etmek, proje geliştirici profesyonelleri arasındaki iletişimi geliştirmek ve yenilik arayışı için inşa edilebilirliğe ihtiyaç duyulmaktadır. Tasarım öncesi arazi ve çevresini, zemin özelliklerini araştırmak, sözleşmeleri düzenlemek, çalışma düzenlerini belirlemek, standardizasyon, tekrarlama, güvenlik düşünülerek tasarım yapmak inşa edilebilir bina yapımını artıracaktır.

Özet olarak; inşa edilebilirliğin kullanılmasının proje yapımında süresiyi kısalttı̆̆ı, maliyet tasarrufu ve verimliliği sağladığı, kalite ve güvenliği artırdığı, daha verimli takım çalışmalarına katkı sağladığı, müşteri memnuniyetini artırdığı ve gereksiz atık oluşumunu azalttığı araştırmalarda ortaya konmuştur. Her iki değerlendirme yöntemi de projeleri asgari düzeyde ve temel inşaedilebilirlik ilkeleri doğrultusunda puanlandıran bir sisteme sahiptir. Ancak, mevcuttaki sistemler büyük ölçekli projelerin değerlendirilmesi için kullanılmak üzere geliştirilmiş, inşaatta verimliliğe odaklanan sistemlerdir. Buna karşın, tekil, orta ve küçük ölçekli projeler genelde bakıldığında özellikle ülkemizde inşaat sektöründe daha büyük bir paya sahiptir. Bu kapsamdaki projelerin sayısının fazlalığı dikkate alındığında özellikle kentsel alanlarda yapılacak dönüşüm projelerinde inşaedilebilirlik değerlendirmesinin yapılmasının önemi ortaya çıkmaktadır. Yukarıda özetlenen hususlar dikkate alındığında, özellikle değişik proje türleri için daha kapsamlı, malzeme seçimi, detaylandırma ve ince yapı uygulama süreçlerini de puanlandıran sistemlerin geliştirilmesi önem taşımaktadır. Günümüz inşaat sektöründe çevre farkındalığının artmasıyla birlikte sürdürülebilir kalkınma bilincine dayalı çalışmaların hız kazanması, dünyada yeşil ürün ve hizmetlerin yaygınlaşmasını da beraberinde getirmiştir. Bu kapsamda çevresel etki değerlendirme sistemleri, yeşil bina sertifika sistemleri ve enerji etkin yapı değerlendirme yöntemleri de inşaat sektöründeki temel araştırma alanlarını oluşturmuştur. Bu araştırmalarda geliştirilen sertifika sistemlerin inşa edilebilirlik değerlendirmeleri ile entegre edilmesinin, çalışma gruplarının (işveren/girişimci, tasarım grubu, yükleniciler, yapım yönetim grubu, proje yönetim grubu ve müteahhitler) daha verimli bir şekilde çalışabilmesini de sağlayacağı, özellikle atık yönetimi konusunda katkı vereceği, çevreye duyarlı yapıların üretilmesi kadar, inşaatta çevreye duyarlı süreç yönetimi yapılabilmesine de olanak tanıyacağı düşünülmektedir.

Sonuç olarak; bu makale kullanılmakta olan inşa edilebilirlik değerlendirmelerinin günümüz şartlarına uyarlanabilmesi için uygulamalı olarak anlaşılabilmesi hedeflenmiştir. Özellikle ülkemizde kapsamlı 
kentsel dönüşüm projelerinin gündemde olduğu bu dönemde, Çevre ve Şehircilik Bakanlığı, belediyeler ve üniversiteki araştırmacıların işbirliği ile, proje onay sürecinde yerel yönetimlerde kullanılmak üzere inşa edilebilirlik değerlendirme sistemlerinin geliştirilmesi desteklenmesi önerilmektedir.

\section{Teşekkür ve Bilgi Notu}

Makalede, ulusal ve uluslararası araştırma ve yayın etiğine uyulmuştur. Çalışmada Etik Kurul izni gerekmemiştir.

\section{Kaynaklar}

Adams, S. (1989). Practical buildability, Construction Industry Research Information Association (CIRIA), Butterworths, London.

Arditi, D., Elhassan, A. ve Toklu, Y.C. (2002). Constructability Analysis in The Design Firm, Journal of Construction Engineering and Management, 128(2), 117-26. doi: 10.1061/(ASCE)07339364(2002)128:2(117).

Barai, S. V. ve Nair, R. S. (2004). Neuro-fuzzy models for constructability analysis, ITcon, 9, 65-73. Erişim Adresi (24.08.2020): https://www.itcon.org/2004/4.

BCA. (2000). Code of Practice on Buildable Design. Building and Construction Authority, Singapore. ISBN 9971-88-745-2.

BCA. (2005). Code of Practice on Buildable Design, Building and Construction Authority, Singapore. Erişim Adresi (24.08.2020): https://docplayer.net/20798161-Code-of-practice-on-buildabledesign-september-2005.html.

BCA. (2011). Code of Practice on Buildability 2011 Edition. Building and Construction Authority, Singapore. Erişim Adresi (24.08.2020): https://www1.bca.gov.sg/docs/default-source/docscorp-news-and-publications/publications/for-industry/buildability-series/copbdapr2011.pdf

BCA. (2017). Code of Practice on Buildability 2017 Edition. Building and Construction Authority, Singapore. Erişim Adresi (24.08.2020): https://www1.bca.gov.sg/docs/default-source/docscorp-news-and-publications/publications/for-industry/buildability-series/cop2017.pdf

Cll Construction Industry Institute. (1986). Constructability: A Primer. Construction Industry Institute, University of Texas, Austin.

CIRIA Construction Industry Research and Information Association. (1979). CIRIA 79: Report for the Year Ending 31st December 1978. CIRIA, London.

CIRIA Construction Industry Research and Information Association. (1983). Buildability: An Assessment. CIRIA, London. ISBN: 08601720239780860172024.

Ferguson, I. (1989). Buildability in Practice, Mitchell Publishing Company Limited, London.

Francis, V. E., Chen, S. E., Mehrtens, V. M., Sidwell, A. C., ve Mc George, W. D. (1999). Constructability Strategy for Improved Project Performance. Architectural Science Review, 42(2), 133-138. doi: 10.1080/00038628.1999.9696866.

Griffith, A. (1987). An Investigation into Factors Influencing Buildability and Levels of Productivity for Application to Selecting Alternative Design Solutions - A Preliminary Report, 646-657. Managing Construction Worldwide, Chartered Institute of Building. CIOB 2.

Ilter, D. (2010). Inşaat Projelerinde Uyuşmazlık Çözüm Yöntemi Seçimi Iç̧in Çok Kriterli Karar Verme Modeli. (Doktora Tezi). İstanbul Teknik Üniversitesi, Fen Bilimleri Enstitüsü, İstanbul.

Kamari, A. A. ve Pimplikar, S. S. (2012). Architectural Designs and Constructability Issues. AKGEC International Journal of Technology, 3(1), 8-17. Erişim Adresi (24.08.2020): https://www.yumpu.com/en/document/view/34614822/architectural-designs-andconstructability-issues. 
Kerridge, A. E. (1993). Plan for constructability, Hydrocarbon Processing, 72(1), 35.

Keskenler, M. ve Keskenler, E. (2017). Bulanık Mantığın Tarihi Gelişimi. Takvim-i Vekayi, 5 (1), 1-10. Erişim Adresi (24.08.2020): https://dergipark.org.tr/tr/pub/takvim/issue/33455/371973.

Lam, P. T. I., Wong, F. W. H. ve Chan, A. P. C. (2006). Contributions of Designersto Improving Buildability and Constructability. Design Studies, 27(4), 457-479. doi: 10.1016/j.destud.2005.10.003.

Lam, P. T. I., Wong, F. W., Chan, A. P. ve Chan, D. W. (2008). Benchmarking Buildability Using the Buildability Assessment Model in Hong Kong. HKIE transactions, 15(1), 7-17. doi: 10.1080/1023697X.2008.10668104.

Lam, P. T. ve Wong, F. W. (2008). Implementing A Buildability Assessment Model For Buildability Improvement. Architectural Science Review, 51(2), 173-184. doi: 10.3763/asre.2008.5121.

Lam, P. T. I. ve Wong F. W. H. (2009). Improving Building Project Performance: How Buildability Benchmarking Can Help. Construction Management and Economics, 27(1), 41-52. doi: 10.1080/01446190802570498.

Low, S. P. ve Abeyegoonasekera, B. (2001). Integrating Buildability in ISO 9000 Quality Management Systems: Case Study of a Condominium Project. Building and Environment, 36(3), 299-312. doi: 10.1016/S0360-1323(00)00004-4.

McGeorge, D., Chen S. E. ve Ostwald M. J. (1992). The Development of a Conceptual Model of Buildability which Identifies User Satisfaction as a Major Objective, CIB Conference, Rotterdam.

Pepper, H. C. (1994). The benefits of constructability reviews during the design of environmental capital projects, Cost Engineering, 36(2), 19-21.

Qing, Y. (2004). Modeling A Decision Support System For Buildable Designs (Doktora Tezi). Singapur Üniversitesi, Singapur.

Touran, A. (1988). Concrete Formwork: Constructability and Difficulties. Civil Engineering Practice, $3(2), 81-88$.

URA. (2019). Handbook on Gross Floor Area. Erişim Adresi (24.08.2020): https://www.ura.gov.sg/Corporate/Guidelines/Development-Control/gross-floor-area.

Wong, F. W. H., Darshi De Saram, D., Lam, P. T. I. ve Chan, D. W. M. (2006). A Compendium of Buildability Issues from the Viewpoints of Construction Practitioners. Architectural Science Review, 49, s.81-90. doi:10.3763/asre.2006.4910.

Wong, F. W. H., Lam, P. T. I. ve Shen, L. Y. (2004). A Dynamic Design Management System for Improving Buildability of Construction. 20th Association of Researchers in Construction Management (ARCOM) Conference. Heriot Watt University. Erişim Adresi (24.08.2020): http://www.arcom.ac.uk/-docs/proceedings/ar2004-0185-0194_Wong_Lam_and_Shen.pdf

Wong, W. H. (2007). Developing and Implementing an Empirical System for Scoring Buildability of Designs in the Hong Kong Construction Industry (Doktora Tezi). The Hong Kong Polytechnic University Department of Building and Real Estate, Hong Kong.

Zolfagharian, S., Nourbakhsh, M., Mydin, S. H., Zin, R. M. ve Irizarry, J. (2012). A Conceptual Method of Constructability Improvement. International Journal of Engineering and Technology, 4(4), 456-459. Erişim Adresi (24.08.2020): http://www.ijetch.org/papers/409-P043.pdf. 